\title{
Share of Tax Filers Claiming EITC Increases Across States and Place Types Between 2007 and 2010 Recession and Policy Changes Associated with Growth
}

\author{
MARYBETH J. MATTINGLY AND ELIZABETH KNEEBONE
}

I n 2009, the American Recovery and Reinvestment Act (ARRA) expanded the Earned Income Tax Credit (EITC), Cone of the nation's most important safety net programs for poor and low-income working American families, ${ }^{1}$ in two targeted ways that both broadened eligibility and increased benefits. First, the phase-in rate and maximum benefit level were increased for large families (those with three or more children), and second, the "marriage penalty" was reduced by increasing the income level at which the EITC starts to phase out for married couples. At the same time, ARRA strengthened the Child Tax Credit for low-income working families by lowering the income threshold at which the credit becomes refundable from $\$ 12,550$ to $\$ 3,000$. After an extension in 2010, these expansions are now set to expire on December 31, 2012.

In this brief, we use Internal Revenue Service tax filing data to show that the share of tax returns claiming the EITC increased between 2007 and 2010, as did the size of the average credit claimed and the number of EITC filers benefitting from the refundable portion of the Child Tax Credit (the Additional Child Tax Credit, or ACTC). While some of these changes can no doubt be attributed to declines in income levels during the Great Recession, the data demonstrate increases across states and different types of communities that are also consistent with the tax credit expansions provided in ARRA. If these expansions are permitted to expire, fewer working families with low incomes will be eligible for the credit, and among those who are eligible, many will see a smaller credit.

\section{Percent of Tax Returns Claiming EITC}

Figure 1 displays the percent of federal tax returns claiming the EITC between 2000 and 2010. A small increase is evident early in the decade, following the 2001 economic downturn and changes to the phase-out rate of married filers claiming the credit. ${ }^{3}$ Rates then remained reasonably steady with a slight dip in 2007 . Concurrent with the onset of the Great Recession in late 2007, EITC rates increased from 2007 to 2009 and remained high in 2010, with one

\begin{abstract}
Key Findings
- $\quad$ One in five federal income tax filers claimed the Earned Income Tax Credit (EITC) in tax year 2010. This represents a 4 percentage point increase since 2007, when just over one in six filers claimed the credit.

- $\quad$ Though the share of filers claiming the EITC varies widely across the country, EITC receipt rose across and within every state following the Great Recession.

- $\quad$ Nationwide, the average value of the EITC per tax return increased \$145 between 2007 and 2010, from $\$ 2,102$ to $\$ 2,247.4$

- The share of EITC filers claiming the Additional Child Tax Credit (ACTC) rose from 44.5 percent in 2007 to 60.4 percent in 2010. On average, EITC filers claiming the ACTC took home an additional $\$ 1,234$ in 2010-up \$223 from 2007.
\end{abstract}

Figure 1. Share of FEDERAL TAX RETURNS ClAIMING EITC 2000-2010 BY PLACE TYPE

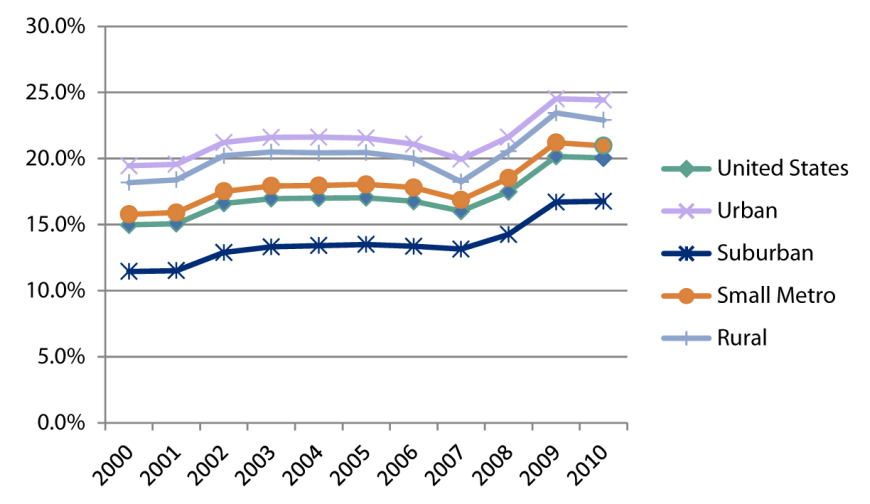

Source: Brookings Institution Analysis of IRS Data 
in five tax filing units benefitting from EITC dollars. The largest increase was observed between 2008 and 2009, likely reflecting the passage of ARRA expansions. Urban and rural places have the highest rates of EITC receipt, but patterns of increase are relatively consistent across place types. These findings suggest the EITC is responsive to changes in the economic cycle as previous research has shown-rising in response to downturns and tapering as it peaks-and that ARRA strengthened that responsiveness following the Great Recession. ${ }^{5}$

All together, there was a 4 percentage point increase in tax returns claiming the EITC between 2007 and 2010 from 16 to 20 percent of tax returns. Table 1 displays state-by-state change in the share of tax returns with EITC claims in 2007 and 2010. In no state or place type did the share of returns claiming the EITC fall during this time. Table 2 shows the five states with the

TABle 1. Share of TAX RetUrns Claiming EITC 2007-2010 By PLACE TYPe (PERCENT)

\begin{tabular}{|c|c|c|c|c|c|c|c|c|c|c|c|c|c|c|c|}
\hline & \multicolumn{5}{|c|}{ Share Claiming EITC 2007} & \multicolumn{5}{|c|}{ Share Claiming EITC 2010} & \multicolumn{5}{|c|}{$\begin{array}{l}\text { Percentage Point Change in } \\
\text { EITC Receipt } 2007 \text { to } 2010\end{array}$} \\
\hline & Total & Urban & Suburban & $\begin{array}{l}\text { Small } \\
\text { Metro }\end{array}$ & Rural & Total & Urban & Suburban & $\begin{array}{l}\text { Small } \\
\text { Metro }\end{array}$ & Rural & Total & Urban & Suburban & $\begin{array}{l}\text { Small } \\
\text { Metro }\end{array}$ & Rural \\
\hline U.S. Total & 16.0 & 19.9 & 13.1 & 16.9 & 18.2 & 20.0 & 24.4 & 16.8 & 21.0 & 22.9 & 4.0 & 4.5 & 3.6 & 4.1 & 4.7 \\
\hline Alabama & 22.8 & 32.3 & 16.6 & 23.1 & 24.6 & 27.9 & 40.0 & 21.4 & 27.7 & 30.8 & 5.2 & 7.7 & 4.8 & 4.6 & 6.2 \\
\hline Alaska & 11.6 & - & - & 10.8 & 13.3 & 13.8 & - & - & 13.0 & 15.7 & 2.2 & - & - & 2.2 & 2.4 \\
\hline Arizona & 16.2 & 17.6 & 12.0 & 20.6 & 22.9 & 21.9 & 24.6 & 15.2 & 27.1 & 29.8 & 5.7 & 7.0 & 3.2 & 6.4 & 6.9 \\
\hline Arkansas & 21.8 & 21.6 & 20.1 & 20.7 & 23.6 & 27.2 & 25.2 & 24.3 & 25.8 & 30.2 & 5.3 & 3.6 & 4.2 & 5.1 & 6.6 \\
\hline California & 15.4 & 16.6 & 14.6 & 16.1 & 14.5 & 19.9 & 21.0 & 19.0 & 20.7 & 19.1 & 4.5 & 4.5 & 4.5 & 4.6 & 4.5 \\
\hline Colorado & 12.2 & 14.9 & 9.7 & 12.1 & 13.3 & 15.9 & 18.8 & 13.1 & 15.7 & 17.9 & 3.7 & 3.9 & 3.4 & 3.6 & 4.5 \\
\hline Connecticut & 10.1 & 21.3 & 8.0 & 10.4 & 9.3 & 12.5 & 25.1 & 10.1 & 12.7 & 11.7 & 2.4 & 3.8 & 2.1 & 2.4 & 2.4 \\
\hline Delaware & 14.2 & - & 12.9 & 16.7 & 15.8 & 17.6 & - & 15.9 & 20.6 & 19.9 & 3.4 & - & 3.0 & 3.9 & 4.1 \\
\hline District of Columbia & 15.9 & 15.9 & - & - & - & 17.4 & 17.4 & - & - & - & 1.5 & 1.5 & - & - & - \\
\hline Florida & 18.7 & 21.4 & 18.6 & 16.7 & 18.4 & 23.7 & 25.1 & 23.8 & 21.4 & 24.9 & 5.0 & 3.7 & 5.3 & 4.7 & 6.5 \\
\hline Georgia & 22.0 & 23.9 & 18.7 & 24.8 & 27.5 & 27.8 & 29.6 & 24.5 & 30.3 & 34.1 & 5.8 & 5.7 & 5.7 & 5.5 & 6.7 \\
\hline Hawaii & 13.7 & 12.0 & 14.0 & - & 15.1 & 17.8 & 17.1 & 16.7 & - & 20.2 & 4.1 & 5.1 & 2.7 & - & 5.1 \\
\hline Idaho & 15.9 & 13.0 & 16.2 & 16.2 & 16.7 & 21.5 & 17.9 & 22.4 & 21.8 & 22.4 & 5.6 & 4.9 & 6.2 & 5.6 & 5.7 \\
\hline Illinois & 14.4 & 20.8 & 11.2 & 14.8 & 15.0 & 17.7 & 24.7 & 14.4 & 17.8 & 18.3 & 3.3 & 3.9 & 3.2 & 3.0 & 3.3 \\
\hline Indiana & 15.2 & 19.6 & 13.2 & 15.3 & 15.1 & 18.9 & 24.0 & 16.5 & 19.1 & 19.0 & 3.7 & 4.4 & 3.2 & 3.9 & 3.9 \\
\hline lowa & 12.5 & 16.7 & 9.7 & 12.4 & 13.0 & 15.4 & 21.1 & 11.9 & 14.9 & 16.3 & 2.9 & 4.4 & 2.3 & 2.5 & 3.3 \\
\hline Kansas & 13.9 & 17.0 & 11.1 & 14.0 & 15.7 & 17.4 & 20.9 & 14.3 & 17.1 & 19.5 & 3.5 & 3.9 & 3.2 & 3.1 & 3.8 \\
\hline Kentucky & 18.0 & 17.2 & 13.9 & 17.1 & 20.5 & 22.8 & 21.1 & 17.7 & 21.2 & 26.8 & 4.8 & 3.9 & 3.8 & 4.1 & 6.3 \\
\hline Louisiana & 24.8 & 30.9 & 20.9 & 24.4 & 27.1 & 29.3 & 35.4 & 24.5 & 28.8 & 33.1 & 4.6 & 4.5 & 3.6 & 4.4 & 6.1 \\
\hline Maine & 13.0 & - & - & 11.8 & 14.8 & 17.0 & - & - & 15.2 & 19.7 & 4.0 & - & - & 3.4 & 4.9 \\
\hline Maryland & 12.7 & 24.6 & 10.8 & 15.6 & 13.6 & 15.4 & 28.9 & 13.3 & 20.1 & 16.4 & 2.7 & 4.4 & 2.5 & 4.5 & 2.8 \\
\hline Massachusetts & 10.0 & 15.8 & 8.9 & 9.6 & 8.8 & 12.6 & 19.5 & 11.3 & 12.4 & 12.3 & 2.7 & 3.7 & 2.4 & 2.8 & 3.5 \\
\hline Michigan & 14.8 & 29.1 & 11.5 & 14.8 & 14.9 & 18.7 & 35.8 & 15.2 & 18.2 & 18.5 & 3.8 & 6.7 & 3.7 & 3.4 & 3.6 \\
\hline Minnesota & 11.0 & 15.6 & 8.4 & 11.7 & 13.1 & 13.8 & 19.1 & 11.0 & 14.6 & 16.3 & 2.8 & 3.5 & 2.5 & 2.8 & 3.2 \\
\hline Mississippi & 28.3 & 39.2 & 22.6 & 23.4 & 30.9 & 35.2 & 45.2 & 27.8 & 29.0 & 39.0 & 6.8 & 6.0 & 5.2 & 5.6 & 8.1 \\
\hline Missouri & 16.2 & 21.6 & 12.4 & 17.0 & 19.4 & 20.3 & 25.8 & 15.8 & 21.4 & 24.7 & 4.1 & 4.2 & 3.4 & 4.4 & 5.3 \\
\hline Montana & 15.0 & - & - & 14.5 & 15.3 & 18.7 & - & - & 17.8 & 19.2 & 3.7 & - & - & 3.3 & 3.9 \\
\hline Nebraska & 13.3 & 15.6 & 9.2 & 12.3 & 14.2 & 16.4 & 18.9 & 11.5 & 15.6 & 17.6 & 3.1 & 3.3 & 2.3 & 3.2 & 3.4 \\
\hline Nevada & 14.3 & 15.2 & 15.2 & 12.2 & 12.5 & 19.6 & 21.1 & 20.8 & 16.5 & 16.1 & 5.3 & 5.9 & 5.6 & 4.3 & 3.6 \\
\hline New Hampshire & 9.6 & - & 8.3 & 9.5 & 10.9 & 12.4 & - & 10.3 & 12.2 & 14.3 & 2.7 & - & 2.1 & 2.7 & 3.3 \\
\hline New Jersey & 11.5 & 31.0 & 10.6 & 14.4 & - & 14.0 & 36.9 & 12.9 & 17.2 & - & 2.5 & 5.9 & 2.4 & 2.7 & - \\
\hline New Mexico & 21.5 & 17.2 & 19.0 & 23.2 & 25.2 & 25.7 & 20.7 & 23.0 & 27.4 & 30.1 & 4.1 & 3.5 & 4.0 & 4.2 & 4.9 \\
\hline New York & 16.3 & 22.4 & 10.0 & 14.2 & 15.5 & 19.6 & 26.8 & 12.3 & 17.3 & 19.1 & 3.4 & 4.3 & 2.3 & 3.1 & 3.6 \\
\hline North Carolina & 18.7 & 17.0 & 15.7 & 18.9 & 21.4 & 23.3 & 20.9 & 19.9 & 23.4 & 27.0 & 4.6 & 3.8 & 4.3 & 4.5 & 5.6 \\
\hline North Dakota & 12.0 & - & - & 10.9 & 12.9 & 13.7 & - & - & 13.0 & 14.3 & 1.7 & - & - & 2.1 & 1.4 \\
\hline Ohio & 14.5 & 22.1 & 11.4 & 15.3 & 15.1 & 18.4 & 27.2 & 14.7 & 19.6 & 19.5 & 3.9 & 5.1 & 3.3 & 4.3 & 4.4 \\
\hline Oklahoma & 18.9 & 19.6 & 16.0 & 23.6 & 20.1 & 23.8 & 24.0 & 20.1 & 29.5 & 26.3 & 4.9 & 4.3 & 4.1 & 5.8 & 6.1 \\
\hline Oregon & 13.2 & 13.0 & 10.5 & 14.1 & 15.7 & 17.0 & 16.5 & 13.6 & 18.3 & 20.5 & 3.8 & 3.5 & 3.1 & 4.2 & 4.8 \\
\hline Pennsylvania & 12.7 & 22.6 & 9.6 & 13.1 & 13.2 & 15.4 & 27.2 & 11.9 & 15.8 & 16.1 & 2.7 & 4.6 & 2.3 & 2.7 & 2.9 \\
\hline Rhode Island & 13.0 & 25.2 & 10.9 & - & - & 16.3 & 30.6 & 13.8 & - & - & 3.3 & 5.4 & 2.9 & - & - \\
\hline South Carolina & 21.1 & 19.4 & 18.7 & 21.8 & 25.5 & 26.0 & 22.7 & 23.1 & 27.6 & 31.3 & 4.9 & 3.3 & 4.4 & 5.7 & 5.8 \\
\hline South Dakota & 14.3 & - & - & 13.1 & 15.4 & 17.3 & - & - & 16.2 & 18.3 & 3.0 & - & - & 3.1 & 2.9 \\
\hline Tennessee & 19.5 & 24.2 & 14.4 & 19.2 & 20.8 & 25.0 & 29.1 & 18.8 & 25.9 & 27.5 & 5.5 & 4.9 & 4.4 & 6.7 & 6.7 \\
\hline Texas & 21.4 & 23.6 & 18.0 & 24.3 & 23.0 & 26.3 & 28.9 & 22.4 & 29.5 & 28.9 & 4.9 & 5.3 & 4.4 & 5.2 & 5.9 \\
\hline Utah & 13.0 & 14.9 & 12.1 & 14.1 & 15.3 & 18.2 & 19.7 & 17.1 & 21.3 & 20.8 & 5.2 & 4.8 & 5.0 & 7.2 & 5.6 \\
\hline Vermont & 11.9 & - & - & 9.9 & 12.8 & 15.0 & - & - & 12.4 & 16.3 & 3.1 & - & - & 2.4 & 3.5 \\
\hline Virginia & 13.6 & 16.0 & 11.2 & 14.7 & 17.5 & 17.1 & 19.1 & 14.3 & 19.1 & 23.2 & 3.5 & 3.0 & 3.1 & 4.4 & 5.6 \\
\hline Washington & 11.6 & 9.8 & 10.0 & 14.1 & 13.8 & 14.7 & 12.2 & 13.0 & 17.7 & 17.5 & 3.1 & 2.4 & 2.9 & 3.6 & 3.7 \\
\hline West Virginia & 16.8 & - & 11.8 & 16.0 & 18.0 & 21.2 & - & 14.9 & 20.0 & 23.2 & 4.5 & - & 3.1 & 4.0 & 5.3 \\
\hline Wisconsin & 11.4 & 19.2 & 7.8 & 11.0 & 11.9 & 14.4 & 22.5 & 10.1 & 14.0 & 15.2 & 3.0 & 3.4 & 2.3 & 3.0 & 3.3 \\
\hline Wyoming & 11.9 & - & - & 13.1 & 11.4 & 14.8 & - & - & 16.1 & 14.3 & 2.9 & - & - & 2.9 & 2.9 \\
\hline
\end{tabular}

Source: Brookings Institution Analysis of IRS Data

Note: Dashes represent the absence of a geography type within a state. 
TABLE 2. STATES WITH THE LARGEST INCREASE IN THE SHARE OF TAX RETURNS CLAIMING EITC 2007-2010 BY PLACE TYPE

\begin{tabular}{ccccc}
\hline Total & Urban & Suburban & Small Metro & Rural \\
\hline Mississippi & Alabama & Idaho & Utah & Mississippi \\
Georgia & Arizona & Georgia & Tennessee & Arizona \\
Arizona & Michigan & Nevada & Arizona & Tennessee \\
Idaho & Mississippi & Florida & Oklahoma & Georgia \\
Tennessee & Nevada & Mississippi & South Carolina & Arkansas \\
\hline
\end{tabular}

Source: Brookings Institution Analysis of IRS Data

largest increase in the percent of tax returns claiming the EITC, nationwide and by place type (in descending order). The largest increases in EITC receipt since the downturn were largely clustered in the South and Intermountain West, with Mississippi posting the largest increase overall. Within states, places with the highest increases in EITC receipt include urban Alabama, suburban Idaho, small metropolitan areas of Utah, and rural Mississippi. The smallest increases were seen across the District of Columbia and North Dakota (not shown).

\section{Value of the EITC and Number of Claims}

Table 3 shows the average value of the credit for tax returns claiming the EITC, as well as the number of returns claiming the credit for 2007 and 2010. In 2010, the average value of the credit was $\$ 2,247$ - an increase of $\$ 145$ over 2007. Urban places had both the largest average credit $(\$ 2,330)$ in 2010 and the greatest increase between 2007 and 2010. The lowest average value in 2010 was in the suburbs at $\$ 2,198, \$ 132$ shy of the typical urban credit.

The suburbs, where America's population is largely concentrated, are home to the largest number-well over a third (38.3 percent) - of EITC filers. Another quarter of filers reside in urban areas (24.8 percent), and the remainder is distributed roughly equally across small metro areas and rural communities (18.8 and 18.1 percent, respectively). Notably, the suburbs experienced the largest increase in the number of tax returns claiming EITC, consistent with trends in the distribution of the broader low-income population over this time period. ${ }^{6}$

\section{EITC Filers Claiming the ACTC}

Table 4 shows the number of EITC tax returns that also claim the ACTC and the average value of the ACTC for 2007 to 2010 by place type. The suburbs are home to the largest number of EITC filers also claiming ACTC. The size of credits claimed reflects a number of factors that can vary across different regions and types of communities, including wage levels and family composition. The value of the ACTC is greatest for suburban EITC filers ( $\$ 1,246$ in 2010). In contrast, rural places had the lowest average ACTC but the greatest increase in average ACTC ( $\$ 310$ ) over this period, bringing them to only $\$ 21$ below the average suburban credit.

\section{Summary}

This brief demonstrates that working Americans increasingly claimed the EITC in the wake of the economic recession, with the greatest increases in the South and Intermountain West. A greater share of those claiming EITC are benefitting from the ACTC, with rural filers seeing the largest increase. Expansions enacted through ARRA enabled more large families and married couples to claim the EITC and strengthened the ACTC for

TAble 3. Number of TAX Returns Claiming EITC AND AVERAge EITC VAluE* 2007-2010 By PLACE TYPE

\begin{tabular}{|c|c|c|c|c|c|c|c|c|c|c|}
\hline & \multicolumn{2}{|l|}{ Total } & \multicolumn{2}{|l|}{ Urban } & \multicolumn{2}{|c|}{ Suburban } & \multicolumn{2}{|c|}{ Small Metro } & \multicolumn{2}{|l|}{ Rural } \\
\hline & $\begin{array}{c}\text { Number of EITC } \\
\text { Tax Returns }\end{array}$ & $\begin{array}{c}\text { Average } \\
\text { Value }\end{array}$ & $\begin{array}{c}\text { Number of EITC } \\
\text { Tax Returns }\end{array}$ & $\begin{array}{c}\text { Average } \\
\text { Value }\end{array}$ & $\begin{array}{c}\text { Number of EITC } \\
\text { Tax Returns }\end{array}$ & $\begin{array}{c}\text { Average } \\
\text { Value }\end{array}$ & $\begin{array}{c}\text { Number of EITC } \\
\text { Tax Returns }\end{array}$ & $\begin{array}{c}\text { Average } \\
\text { Value }\end{array}$ & $\begin{array}{c}\text { Number of EITC } \\
\text { Tax Returns }\end{array}$ & $\begin{array}{c}\text { Average } \\
\text { Value }\end{array}$ \\
\hline 2007 & $23,753,597$ & $\$ 2,102$ & $5,891,851$ & $\$ 2,173$ & $8,823,920$ & $\$ 2,052$ & $4,516,050$ & $\$ 2,103$ & $4,521,776$ & $\$ 2,107$ \\
\hline 2010 & $25,931,295$ & $\$ 2,247$ & $6,418,397$ & $\$ 2,330$ & $9,942,651$ & $\$ 2,198$ & $4,881,432$ & $\$ 2,239$ & $4,688,815$ & $\$ 2,245$ \\
\hline Change & $2,177,698$ & $\$ 145$ & 526,546 & $\$ 157$ & $1,118,731$ & $\$ 146$ & 365,382 & $\$ 136$ & 167,039 & $\$ 138$ \\
\hline
\end{tabular}

Source: Brookings Institution Analysis of IRS Data; ${ }^{*}$ In 2010 dollars.

TAble 4. Number of EITC returns Claiming ACTC ANd AVERAge VAlue* 2007-2010 by PLACE Type

\begin{tabular}{|c|c|c|c|c|c|c|c|c|c|c|}
\hline & \multicolumn{2}{|c|}{ Total } & \multicolumn{2}{|c|}{ Urban } & \multicolumn{2}{|c|}{ Suburban } & \multicolumn{2}{|c|}{ Small Metro } & \multicolumn{2}{|l|}{ Rural } \\
\hline & $\begin{array}{c}\text { Number of EITC } \\
\text { Tax Returns } \\
\text { with ACTC }\end{array}$ & $\begin{array}{c}\text { Average } \\
\text { Value }\end{array}$ & $\begin{array}{c}\text { Number of EITC } \\
\text { Tax Returns } \\
\text { with ACTC }\end{array}$ & $\begin{array}{c}\text { Average } \\
\text { Value }\end{array}$ & $\begin{array}{c}\text { Number of EITC } \\
\text { Tax Returns } \\
\text { with ACTC }\end{array}$ & $\begin{array}{c}\text { Average } \\
\text { Value }\end{array}$ & $\begin{array}{c}\text { Number of EITC } \\
\text { Tax Returns } \\
\text { with ACTC }\end{array}$ & $\begin{array}{c}\text { Average } \\
\text { Value }\end{array}$ & $\begin{array}{c}\text { Number of EITC } \\
\text { Tax Returns } \\
\text { with ACTC }\end{array}$ & $\begin{array}{c}\text { Average } \\
\text { Value }\end{array}$ \\
\hline 2007 & $10,565,591$ & $\$ 1,011$ & $2,598,501$ & $\$ 923$ & $4,023,833$ & $\$ 982$ & $1,990,350$ & $\$ 964$ & $1,952,907$ & $\$ 915$ \\
\hline 2010 & $15,667,155$ & $\$ 1,234$ & $3,911,711$ & $\$ 1,226$ & $5,974,229$ & $\$ 1,246$ & $2,966,046$ & $\$ 1,228$ & $2,815,169$ & $\$ 1,225$ \\
\hline Change & $5,101,564$ & $\$ 223$ & $1,313,210$ & $\$ 303$ & $1,950,396$ & $\$ 264$ & 975,696 & $\$ 264$ & 862,262 & $\$ 310$ \\
\hline
\end{tabular}


EITC filers with children, increasing the value of these credits for many. Using its comprehensive supplemental poverty measure, the U.S. Census Bureau estimates that these expanded credits kept millions of children and families out of poverty and lowered the poverty rate by 2.8 percentage points overall, and by 6.3 percentage points for children in $2011 .^{7}$ Should these expansions be allowed to expire at the end of 2012, eligibility and benefit levels will decline for these families, diminishing the impact of these credits, even as many continue to struggle with the aftereffects of the recession.

\section{Data}

Data on tax filers are derived from ZIP code-level estimates provided by the Internal Revenue Service's Stakeholder, Partnerships, Education, and Communication (SPEC) Return Information Databases. The Brookings Institution analyzed and allocated the data to create estimates at higher levels of geography, including cities, counties, and metropolitan areas. ${ }^{8}$ Data for tax years 2000 through 2008 represent all tax returns filed in a given tax year. Due to recent changes in the SPEC database, data for tax years 2009 and 2010 include returns filed between January and June, which generally account for more than 90 percent of all returns filed in a tax year. ${ }^{9}$ For the purposes of this analysis, the 100 largest metro areas-which are home to two-thirds of the nation's population-are divided into "urban" and "suburban" areas. "Urban" areas include cities that appear first in the official metropolitan statistical area name, as well as any other city in the metro area name with a population of 100,000 or more. "Suburbs" represent the remainder of the metro area outside of urban places. "Small metro areas" include the remaining 266 metro areas designated by the Office of Management and Budget. "Rural" areas represent all counties not included in an official metropolitan statistical area.

\section{E N D N O T E S}

1. For example, according to the Center on Budget and Policy Priorities, "In 2010, the EITC lifted about 6.3 million people out of poverty, including about 3.3 million children." See www.cbpp.org/cms/index.cfm?fa=view\&id=2505.

2. See www.irs.gov/uac/ARRA-and-the-Earned-Income-TaxCredit.

3. See www.nber.org/cycles.html. The 2001 marriage penalty relief was included in the Bush tax cuts, which are also set to expire.

4. All dollar values are inflation-adjusted to 2010 dollars.

5. Elizabeth Kneebone and Emily Garr, "Responding to the New Geography of Poverty: Metropolitan Trends in the Earned Income Tax Credit" (Washington: Brookings Institution, 2011).

6. See www.theatlanticcities.com/politics/2012/09/changing- geography-metropolitan-poverty/3348/, www.theatlanticcities.com/jobs-and-economy/2011/09/rapid-growthsuburban-poor/190/, and www.brookings.edu/research/ papers/2010/10/07-suburban-poverty-acs-kneebone.

7. See www.census.gov/hhes/povmeas/methodology/supplemental/research/Short_ResearchSPM2011.pdf.

8. These data are available online through the Brookings Institution's EITC Interactive application. For more information, see www.brookings.edu/about/programs/metro/eitc/eitc-data.

9. In tax year 2010, the part-year data capture 94 percent of all tax filers and 97 percent of EITC filers. For more information on these data issues, see www.brookings.edu/ /media/ Programs/metro/EITC/interactive\%20data\%20brief.pdf.

\section{ABOUT THE AUTHORS}

Beth Mattingly is director of research on vulnerable families at the Carsey Institute and a research assistant professor of sociology at the University of New Hampshire (beth.mattingly@unh.edu).

Elizabeth Kneebone is a fellow at the Brookings Institution's Metropolitan Policy Program (EKneebone@brookings.edu).

\section{A C K N O W LE D GE M E N T S}

The authors thank Jane Williams at the Brookings Institution for her research assistance and Jessica Carson, Curt Grimm, Laurel Lloyd, Bruce Mallory, and Amy Sterndale at the Carsey Institute for comments and editorial assistance.

\section{ANIVERSITY}

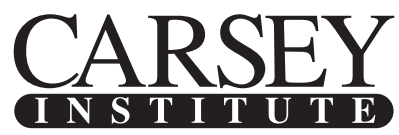

\section{Building knowledge for families and communities}

The Carsey Institute conducts policy research on vulnerable children, youth, and families and on sustainable community development. We give policy makers and practitioners timely, independent resources to effect change in their communities.

This work was supported by the Annie E. Casey Foundation, the W. K. Kellogg Foundation, and anonymous donors.

Huddleston Hall

73 Main Street

Durham, NH 03824

(603) $862-2821$

\section{www.carseyinstitute.unh.edu}

